BASINDO : Jurnal Kajian Bahasa, Sastra Indonesia, dan Pembelajarannya

Volume 2 Nomor 1, 2018

Journal homepage : http://journal2.um.ac.id/index.php/basindo

\title{
PERGESERAN DAN PEMERTAHANAN BAHASA ALUNE DESA MURNATEN KECAMATAN TANIWEL KABUPATENSERAM BAGIAN BARAT AMBON
}

\author{
Yohanis Hukubun ${ }^{*}$ \\ Universitas Negeri Malang, Indonesia
}

\begin{tabular}{|c|c|}
\hline ARTICLE INFO & A B S T R A C T \\
\hline $\begin{array}{l}\text { Keyword: } \\
\text { Pergeseran Bahasa, } \\
\text { Pemertahanan Bahasa, } \\
\text { Bahasa Alune, } \\
\text { Masyarakat Tutur Bahasa }\end{array}$ & $\begin{array}{l}\text { Penelitian ini bertujuan mengkaji pergeseran dan pemertahanan bahasa Alune desa } \\
\text { Murnaten Kecamatan Taniwel Kabupaten Seram Bagian Barat Ambon, Provinsi Maluku. } \\
\text { Pendekatan yang digunakan adalah pendekatan desktriptif kualitatif. Hasil penelitian } \\
\text { menunjukkan adanya (1) pola penggunaan bahasa Alune, (2) pergeseran bahasa Alune,(3) } \\
\text { faktor pendorong pergeseran bahasa Alune,(4)tipe pemertahanan bahasa Alune,(5)faktor } \\
\text { pemertahanan Bahasa Alune,dan (6) strategi pemertahanan bahasa Alune di desa } \\
\text { Murnaten Kecamatan Taniwel Kabupaten Seram Bagian Barat Ambon. }\end{array}$ \\
\hline
\end{tabular}

\section{PENDAHULUAN}

Bangsa Indonesia terdiri atas ratusan etnik yang berbeda-beda. Masing-masing etnik memiliki karakter yang berbeda pula. Perbedaan etnik tersebut berdampak pada kebervariasian/keberagaman bahasa yang digunakan oleh masing-masing etnik. Kebervariasian bahasa tersebut tidak hanya terjadi pada penggunaan bahasa daerah (bahasa ibu) tetapi juga terjadi pada pemakaian bahasa Indonesia. Karena itu, pemakaian bahasa Indonesia masing-masing etnik juga memiliki variasi berdasarkan peristiwa tutur dan situasi tutur. Jadi, dapat disimpulkan bahwa etnis yang beragam tersebut menjadi salah satu factor terjadinya keanekaragaman bahasa di Indonesia.

Kehidupan bermasyarakat tidak terlepas dari hubungan-hubungan sosial di dalamnya. Ketika terjadi interaksi social di situ pun bahasa juga berperan penting dalam interaksi tersebut. Hal ini berarti bahwa terjadinya hubungan atau kontak social di dalam masyarakat akan berjalan dengan baik, jika bahasa turut berperan untuk menjawab kebutuhan komunikasi dalam masyarakat (Ramadhanti, 2018). Karena itu, bahasa dan masyarakat tidak dapat dipisahkan dan saling berhubungan antara keduanya sebab bahasa hidup dalam masyarakat dalam Siregar, BahreinUmar, dkk. (1998). Pemertahanan Bahasa dan Sikap Baha Pergeseran bahasa (language shift) menyangkut masalah penggunaan bahasa oleh seseorang penutur atau sekelompok penutur yang bisa terjadi sebagai akibat perpindahan dari satu masyarakat tutur ke masyarakat tutur lain (Chaer dan Agustina, 2004:142). Hal ini dimaksudkan bahwa pergeseran bahasa dimungkinkan terjadi karena perpindahan penduduk dari satu tempat ke tempat yang lain dengan tidak mempertahankan bahasa yang dimiliki. Oleh sebab itu, bahasa dari kelompok tersebut mengalami pergeseran karena dipengaruh lingkungan yang baru.

Dalam penelitian ini, peneliti mengambil Bahasa Alune di Desa Murnaten Kecamatan Taniwel Kabupaten Seram Bagian Barat/Ambon. Desa Murnaten Kecamatan Taniwel Kabupaten Seram Bagian Barat merupakan salah satu bagian dari kota Ambon karena kota Ambon adalah ibu kota Provinsi Maluku. Desa Murnaten Kecamatan Taniwel Kabupaten Seram Bagian Barat, terletak pada pesisir pantai di pulau Seram. Kemudian berdasarkan penelusuran yang telah dilakukan, terdapat bahwa masyarakat Desa Murnaten, ketika berkomunikasi tidak lagi menggunakan bahasa Alune, tetapi adanya pencampuran bahasa yaitu bahasa Alune, bahasa Melayu Ambon dan bahasa Indonesia. Selain itu, masyarakat tutur bahasa Alune

\footnotetext{
* Corresponding author.

E-mail addresses: dian_eka09@yahoo.com (Dian Eka Chandra Wardhana)
}

ISSN : 2579-3799 (Online) - BASINDO : Jurnal Kajian Bahasa, Sastra Indonesia, dan Pembelajarannya is licensed under Creative Commons Attribution-ShareAlike 4.0 International License (http://creativecommons.org/licenses/BY/4.0/).

55 | BASINDO : Jurnal Kajian Bahasa, Sastra Indonesia, dan Pembelajarannya 
sebagian besar telah menggunakan bahasa Melayu Ambon. Untuk penggunaan bahasa Alune (bahasa adat) asli Desa Murnaten tersebut, jarang digunakan oleh masyarakat Murnaten ketika berkomunikasi dengan mitratuturnya. Hal ini disebabkan oleh sebagian besar masyarakat tersebut telah menggunakan bahasa Melayu Ambon dalam kehidupan sehari-hari. Hal ini terjadi karena bahasa yang sangat dominan yang digunakan masyarakat Murnaten yaitu bahasa Melayu Ambon. Pada penelusuran awal, peneliti juga melihat langsung bahwa dalam musyawarah-musyawarah desa, bahasa yang digunakan bukan bahasa Alune (bahasa adat) tetapi bahasa Melayu Ambon. Bahasa Indonesia, hanya digunakan dalam konteks sekolah tetapi bahasa Indonesia yang berada di sekolah pun dipengaruhi juga oleh bahasa Melayu Ambon.

Berdasarkan penulusuran awal yang dilakukan penelitidi Desa Murnaten, peneliti menemukan penggunaan bahasa Alune(bahasa adat) hanya digunakan oleh orangtua yang berusia 46 keatas. Hal ini disebabkan karena orang tua yang berusia 46 tahun keatas masih menggunakan bahasa Alune dalam komunikasi mereka. Namun, bahasa yang digunakan oleh orang tua yang berusia 46 tahun ke atas kepada anak-anak, yaitu bahasa Melayu Ambon dan bukan bahasa Alune. Alasan yang mendasari bahasa Melayu Ambon digunakan oleh orangtua yang berusia 46 tahun keatas kepada anak-anak tetapi bukan bahasa Alune, karena anak-anak di Desa Murnaten hanya dapat mengerti dan menggunakan bahasa Melayu Ambon dalam komunikasi sehari-hari.

Salah satu contoh kasus penggunaan bahasa adalah sebutan untuk ibu dalam bahasa Alune Desa Murnatenina. Seharusnya penggunaan bahasa Alune untuk sebutan ina digunakan sehari-hari untuk menyebut seorang ibu. Namun, dalam penelitian awal yang dilakukan, peneliti menemukan hal yang berbeda dalam penggunaan bahasa Alune untuk sebutan ina pada masyarakat Murnaten. Hal yang berbeda tersebut yaitu untuk penggunaan sebutan ina hanya dapat digunakan oleh orang tua berusia 46 tahun ke atas, untuk menyapa orangtua mereka. Hal ini berbeda dengan anak-anak berusia 5-11 tahun di Desa Murnaten, karena seharusnya bahasa yang digunakan kepada orangtua mereka (ibu) adalah bahasa Alune dengan sebutan ina. Akan tetapi, dalam kenyataannya anak- anak berusia 5-11 tahun di Desa Murnaten tidak lagi menggunakan sebutan ina untuk ibu mereka, melainkan sebutan mama.

Berdasarkan latar belakang penelitian tersebut, penelitian ini bertujuan untuk;

a. Menemukan pola penggunaan bahasa Alune di Desa Murnaten Kecamatan Taniwel Kabupaten Seram Bagian Barat Ambon.

b. Menemukan pergeseran bahasa Alune di Desa Murnaten Kecamatan Taniwel Kabupaten Seram Bagian Barat Ambon.

c. Menemukan factor yang mendorong pergeseran bahasa Alune di Desa Murnaten Kecamatan Taniwel Bagian Barat pemertahanan bahasa Alune di Desa Murnaten, Kecamatan Taniwel Kabupaten Seram Bagian Barat Ambon.

e. Menemukan factor pemertahanan Bahasa Alune di Desa Murnaten Kecamatan Taniwel Kabupaten Seram Bagian Barat Ambon.

f. Menemukan strategi pemertahanan bahasa Alune di Desa Murnaten Kecamatan Taniwel Kabupaten Seram Bagian Barat Ambon.

\section{METODE PENELITIAN}

Penelitian ini merupakan penelitian sosiolinguistik yang mendeskripsikan fenomena pergeseran dan pemertahanan bahasa Alune di Desa Murnaten, Kecamatan Taniwel, Kabupaten Seram Bagian Barat, Ambon. Kajian peneilitan ini merupakan kajian sinkronis, yaitu kajian tentang fenomena bahasa dalam satu masa. Pendekatanpenelitianiniyangdigunakan adalah pendekatan kualitatif dengan metode deskriptif. Penelitian ini dilakukan kepada informanasli di DesaMurnaten,Kecamatan Taniwel, Kabupaten Seram Bagian Barat, Ambon.

Pengambilandatadalampenelitianini dilakukansecara langsung di lokasi penelitian dengan menggunakan subjek penelitian sebagai sumber data. Penelitian ini dilakukan secara alamiah dan menggunakan subjek sebagai informan penelitian. Subjek dibagi atas dua kelompok, yaitu kelompok tua (usia 46 ke atas) dan kelompok anak-anak (usia 5-11 tahun). Dalam penelitian ini peneliti menggunakan 120 subjek penelitian

Metode penelitian yang digunakan, yaitu metode simak,metode survey, dan metode cakap. Teknik pengumpulan data dalam penelitian digunakan teknik sadap, teknik angket, teknik wawancara. Instrumen yang digunakan dalam peneltian pergeseran dan pemertahanan Bahasa Alune di Desa Murnaten Kecamatan Taniwel Kabupaten Seram Bagian Barat Ambon, yaitu human istrument, angket, catatan kecil, kamera digital, kamera video, glos 662 kosakata dan100 kalimat.

Teknik analisis data penelitian ini digunakan teknik analisis deskriptif yang diawali dengan kegiatan pengkategorian data, menginterpretasi data, dan penyimpulan. Kegiatan ini dilakukan dengan berdaur yang diawali dengan pengumpulan data, reduksi data, pemaparan data dan simpulan. 
HASIL PENELITIAN DAN PEMBAHASAN

\section{A. Pola Penggunaan Bahasa Alune di Desa Murnaten Kecamatan Taniwel Kabupaten Seram Bagian Barat Ambon.}

Penelitian yang dilakukan peneliti untuk mendapatkan data mengenai pola penggunaan bahasa Alune di Desa Murnaten Kecamatan Taniwel Kabupaten Seram Bagian Barat Ambon, ditemukan tiga pola penggunaan bahasa Alune. Peneliti mendapatkan data tersebut dari hasil wawancara dan pengelolaan angket penelitian yang dibagikan kepada subjek penelitian. Tiga pola penggunaan bahasa Alunedi Desa Murnaten kecamatan Taniwel Kabupaten Seram Bagian Barat Ambon, yaitu (1) pelantikan pemimpin desa atau yang disebut raja, (2) pelaksanaan pelamaran seorang wanita untuk dinikahi atau yang disebut masuk minta. Dalam pelaksanaan pelamaran atau masukminta terbagi lagi atas tiga, yaitu (a) pelamaran resmi atau masuk minta resmi, (b) kawin menua, (c) kawin lari, dan (3) ketika orang tua berumur 46 keatas bertemu dengan usia yang sama maka pada saat itulah bahasa Alune digunakan.

1. Pelantikan PemimpinDesa/Raja

Pelantikan pemimpindesa/raja, bahasa yang digunakan, yaitu bahasa Alune yang sesuai dengan ketentuan adat yang berlaku di Desa Murnaten Kecamatan Taniwel Kabupaten Seram Bagian Barat Ambon. Fungsi penggunaan bahasa Alune atau bahasa adat di Desa Murnaten dalam pelantikan pemimpin/raja memiliki beberapa fungsi, yaitu untuk memangil leluhur hadir dalam pelaksanaan pelantikan raja dan untuk menasehati pemimpin desa/raja yang telah dilantik. Oleh sebab itu, bahasa Alune atau bahasa adat yang digunakan saat pelaksanaan pelantikan raja sangatlah sakral. Jadi, orang yang menggunakan bahasa tersebut harus dapat mengerti dan dapat menggunakan bahasa Alune dengan benar. Selanjutnya, orang tersebut haruslah dari marga atau mata rumah yang telah diutus leluhur. Penggunaan bahasa Alune atau bahasa adat Desa Murnaten Kecamatan Taniwel Kabupaten Seram Bagian Barat Ambon, dapat dilihat sebagai berikut.

00000...3x Akupua aku sia tuana mata binana

bei mete ulate kai batua bei mete

takuwa mene kai hena buini

$00000 \ldots 3 x$

Mai selu ami mina petu meire

ami sake ama latu

bei luma mata lumbau

lopai sisine

lekai selu hena meire

Pinake petu luwa

sou pasate luwake kuwai tuane kese beini yake

kele kukuru Tuane ama latu petu meire

hena tai ulete ale kerike peneka

elekai uwabuai emebalamu lalei peneka

pinake petu luwa pina sou tilina ale kese mo

tele kukuru

saka nunuwe bali tulase elekai pinake petu luwa ulane aini

ale kese mo kele kukuru

rilamu yake tuane mata binane kese beimu mo

\section{PelamaranSeorangGadis untukDinikahi/Masuk Minta}

Penelitian yang dilakukan peneliti mengenai pola penggunaan bahasa Alune yang digunakan dalam pelaksanaan pelamaran seorangga disuntuk dinikahi/masuk minta di Desa Murnaten, ditemukan tiga data. Ketiga data mengenai pola penggunaan bahasa Alune di Desa Murnaten Kecamatan Taniwel Kabupaten Seram Bagian Barat Ambon, yaitu (1) pelamaran atau masuk minta secarar esmi, (2) kawin menua, dan (3) kawin lari.

a. Pelamaran atau Masuk Minta Resmi

Pelaksanaan pelamaran atau masuk minta resmi, terjadi karena kemauan laki- laki dan perempuan dengan cinta mereka yang telah kokoh sehingga mereka telah sepakat untuk melanjutkan hubungan ke jenjang yang lebih serius, yaitu pernikahan. Dalam pelaksanaan pelamaran, masing- masing keluarga akan bertemu dan menunjuk salah satu tokoh dari keluarga mereka yang akan berbicara dengan menggunakan bahasa Alune. Hal ini sebabkan karena tidak semua keluarga perempuan dan laki-laki tidak dapat berbahasa Alune dan tidak mengetahui aturan adat yang berlaku dalam pelaksanaan pelamaran. Pola 
penggunaan bahasa Alune atau bahasa adat dalam pelaksanaan pelamaran/masuk minta resmi, dapat dilihat sebagai berikut.

Pihaklaki-laki: amiromalumalakametu lakwai telu tok..tok...tok...tok...

Pihak perempuan: imi syami meru?

Pihak laki-laki: ami bei luma matamokwai,amiluwakekaiamikisou nai mei

Pihak perempuan: imi luwake kai sou misetepi be sou tayae

Pihak laki-laki: sou misete

Pihak perempuan: mai luma toini kusu lomei Pihakperempuan:epo,imiluwakemeire sou anai pisou? sopo elemeirealenakelekeiti alaha lokole

Pihaklaki-laki: lamatekenamiKasounai meire kouwe au moneka Au luwake meire, halete laleku sapa imi mi manu bina inai ete mere! au kusou meire sopo kalu imi rapie neka masike emiri ebulu po au likuwe.

Pihakperempuan:Ina,ImimiSoumeire MisetePenekaPo,ka ami ki manu bina meire matekwa mo

Pihak laki-laki: ina, masike be emise pise mo pise po laleku kenae

Pihakperempuan: monekei sopoimi seseke kwanekasosebeye imi neka

Pihaklaki-laki:somoneka,souree matekwa meire peneka amikinia imi laleke? Sopo sou saisasoimi beteke neka, lekena ami leure yo ami rekwa laleke.

Pihakperempuan: monekei,sai lepasousamoneka le atate iti rekwa pero

Pihaklaki-laki: iyo,masike atate iti rekwa po imi beteke laleke lekena ami rekwa laleke!

Pihak perempuan: uluweli, inai ni labate kai memei eini maka ota

Pihakperempuan:moneka,meireitilepa sousa moneka, so imi binaru selu kwa yelu mere lomei noma.

Pihak laki-laki: moneka! Auku, mobu toya

imi ka iti losa nai kai kinu kwelea kai soso pakua pelapeneso ka ami leu bei imi neka.

Pihakperempuan: lamate kenami! Imi leurepo,itikanesauulu misetasesimo,poimi lepa ami yake.

Pihak laki-laki: au, iti kane kinu kwele soso pakua so merenebe saisa lekwe.

Pihakperempuan: hio,lamate kenapusuminoma

\section{b. Kawin Menua}

Kawin menua mempunyai, arti seorang lelaki telah membawah dirinya untuk tinggal di rumah pihak perempuan (pacarnya) tanpa diketahui oleh orangtua dari kedua pihak. Sebelum pelaksanaan pelamaran (kawinmenua) keluarga keluaraga laki-laki akan melaksanakan pertemuan keluarga untuk menunjuk salah satu tokoh dari keluarga mereka untuk pergi ke rumah perempuan dan memberitahukan bahwa besok keluarga laki-laki akan ke rumah pihak perempuan. Masing-masing dari kedua pihak akan melaksanakan pertemuan keluarga sebelum pelaksanaan pelamaran, untuk menentukan salah satu tokohdari keluarga mereka untuk berbicara dengan menggunakan bahasa Alune. Hal tersebut dilakukan karena tidak semua anggota keluarga mengetahui dan memahami bahasa Alune dan aturan adat yang berlaku dalam pelaksanaan pelamaran.

Percakapan antara utusan pihak laki-laki dengan pihak perempuan dengan menggunakan bahasa Alune sebagai alat komunikasi di Desa Murnaten dapat dilihat sebagai berikut.

Utusan Pihak laki-laki:pinake kena kamau ami hole lomei

Pihak Perempuan: iyo, kalu pita kena kamauluma makwai si hole lomei, si hole lomei yo lomei nepi Dalampelaksanaan pelamaran mengenai kawin menua yang dilaksanakan oleh keluarga pihak lakilaki dengan keluarga pihak perempuan, pola penggunaan bahasa Alune yang digunakan sebagai alat komunikasi di Desa Murnaten dapat dilihat sebagai berikut.

Pihak laki-laki:ami roma luma laka metu lakwai telu

Pihak perempuan:imisyami meru?

Pihak laki-laki:ami bei luma matamakwai, amiluwakekaiamikisounai mei

Pihak perempuan: imi luwake kai sou misetepi be sou tayae

Pihak laki-laki: sou misete

Pihak perempuan: mai luma toini kusu lomei

Pihak perempuan: imi lomei ono saisa?

Pihaklaki-laki: ami luwake nikwa loko ami

ki manu tulale inai sae, ekae be luma petua ila meire peneka

Pihak perempuan:iyo, manu tulale meire sasapaini mei luma lalei petuailaru meirepeneka, ami susuiye yo ekeuw tekwa bei luma lalei mo.

Pihaklaki-laki:souremisetemeirepeneka po, ami ki manu tulale inai mere e matekwa mo. 
Sou moneka, meire saikowe lomai moneka.

Pihakperempuan:maiere ami beteke ete imi

ata neka.

Pihak laki-laki:so eleka? ami ki manu tulale meireeruwekaiimi mi

manubinamereso eleka?

Pihakperempeuan:monekei,luwalu maukwe lomai peneso, seberua noma

Pihak laki-laki:so moneka, souree matekwa meire peneka ami kinia imi laleke?Sopo sou saisa

soimibetekeneka, lekenaami leure yo ami rekwa laleke.

Pihakperempuan:monekei,sailepasousa

moneka le atate iti rekwa pero

Pihak laki-laki:iyo, masike atate iti rekwa po

imi beteke laleke lekena ami rekwa laleke!

Pihakperempuan:uluweli,inai ni labate kai memei eini maka ota

Pihakperempuan:moneka,meireitilepa

sousa moneka, so imi binaruselukwayelu mere lomei noma.

Pihaklaki-laki:moneka!Auku,mobutoya imi/kaitilosanaikai

kinu kwelea kai soso pakua pelapeneso ka ami leu bei imi neka.

Pihakperempuan:lamatekenami!Imileure

po,itikanesauulu

misetasesimo,poimi lepa ami yake.

Pihaklaki-laki:au,iti kane kinukwele soso pakua so merenebe saisa lekwe.

Pihakperempuan: hio,lamate kenapusumi noma.

\section{c. Kawin Lari}

Kawin lari artinya seorang laki-laki dan perempuan lari dari rumah mereka tanpa diketahui oleh orang tua. Sebelum pelaksanaan pelamaran (kawin menua) keluarga keluaraga laki-laki akan melaksanakan pertemuan keluarga untuk menunjuk salah satu tokoh dari keluarga mereka untuk pergi ke rumah perempuan dan memberitahukan bahwa besok keluarga laki-laki akan ke rumah pihak perempuan. Masing-masing dari kedua pihak akan menlaksanakan pertemuan keluarga sebelum pelaksanaan pelamaran, untuk menentukan salah satu tokoh dari keluarga mereka untuk berbicara dengan menggunakan bahasa Alune. Hal tersebut dilakukan karena tidak semua anggota keluarga mengetahui dan memahami bahasa Alune dan aturan adat yang berlaku dalam pelaksanaan pelamaran. berikut.

Pola penggunaan bahasa Alune oleh utusan pihak laki-laki dan perempuan dapat dilihat sebagai

UtusanPihaklaki-laki:pinakekenakamau ami hole lomei

Pihak Perempuan: iyo, kalu pita kena kamau luma makwai si hole lomei, si hole lomei yo lomei nepi

PolapenggunaanbahasaAluneyang

digunakandalamprosespelamaranatau masukmintamengenaikawinlaridapat dilihatsebagai berikut. Pihaklaki-laki: ami romalumalaka metu lakwai telu

Pihak perempuan:imisyami meru?

Pihak perempuan: mai luma toini kusu lomei

Pihaklaki-laki:aukeriruwakumeire

peneka,imi ono au eleka pi eleka pi sebeye imi neka, au lomei likuku salale.

Pihak perempuan: atami ruwe mina, pina iti

lepa sa

Pihaklaki-laki:ami luwake meire,ami keri, ami ki salale, ete imi halete memanepetunaluwa kwetele luwa ru esi ono imi wamar tetu, peneka so mula moneka be emiri ebulu po ami likuwe.

Pihaklaki-laki: somoneka, souree matekwa meire peneka ami kiniaimi laleke?Soposou saisa so imi beteke neka, lekena ami leure yo ami rekwa laleke.

Pihakperempuan: monekei,sai lepasousa moneka le atate iti rekwa pero

Pihaklaki-laki: iyo,masike atate iti rekwa

po imi beteke laleke lekena ami rekwa laleke!

Pihak perempuan: uluweli, inai ni labate kai

memei eini maka ota

Pihakperempuan:moneka,meireitilepa

sousa moneka, so imi binaruselukwayelu mere lomei noma. 
Pihak laki-laki: moneka! Auku, mobu toya imi/kaitilosanaikai kinu kwelea kai soso pakua pelapeneso ka ami leu bei imi neka

Pihak perempuan: lamate kenami!

Imi leure po, iti kane sau

ulu miseta sesi mo, po imi lepa ami yake.

Pihak laki-laki: au, iti kane kinu kwele soso

pakuasomerenebesaisa lekwe.

Pihakperempuan: hio,lamate kenapusumi noma

\section{Percakapan orang tua}

Penggunaan bahasa Alune digunakan juga dalam komunikasi antara orangtua 46 tahun keatas dengan orang tua yang seumuran Desa Murnaten Kecamatan Taniwel Kabupaten Seram Bagian Barat Ambon. Dalam komunikasi terdapat dua bahasa yang digunakan, yaitu Bahasa Alune dan Bahasa Melayu Ambon.

Orang pertama: Pina kena kenamu

Orang kedua:E, pina kena kenamu wat, Keupai minu?

Orang pertama: Menere pe, keu petu telu

paiminu peneka

Orang kedua: Ami kane mau Hahahhhaha

Orang pertama: Au perlu kai ale

Orang kedua: Mai ruwe mina?Ale kane peneko?

Orang pertama: Elo au kane penekaAku bina mei ono mananekwetele etinei kane

Orang kedua: Ami kane pia kai utaloini Ulane meirso ite ono saisa moneka

Orang pertama: Menerene ulane meire so, itiki aisa mau Hahahhae, Ina Ami kane mo

Orang kedua: Mone po?

Orang pertama:Auh keu mosa, au mei sibukmey sa?

Orang kedua: Mula mo?Orang pertama:ami mei pleseter luma saOrang kedua: Oh iyo, Ami au kai kwetelelume kerike saOrang pertama:elo keu no, Elo au ono lumalalei mina,elo so au keuw mina.

Orang kedua; Iyo totonaimina, au keuw sa.

\section{B. Pergeseran Bahasa Alune Di Desa Murnaten Kecamatan Taniwel Kabupaten Seram Bagian Barat Ambon}

Data ini di dapatkan melalui hasil sadap/dengan menggunakan handphone yang dapat merekam percekapan satu keluarga yang terdapat beberapa orang yaitu ibu/bapak, anak, paman yang menggunakan bahasa dalam ranah keluarga dan konteksnya di depan rumah, pada siang. Penggunaan bahasa pada ranah keluarga tersebut digunakan untuk topik pembicaraan masalah sehari-hari dalam keluarga dengan menggunakan bahasa Melayu Ambon dan Bahasa Indonesia. Tidak ditemukan penggunaan Bahasa Alune dalam anggota keluarga antara ayah, ibu dan anak di Desa Murnaten Kecamatan Taniwel Kabupaten Seram Bagian Barat Ambon.

A:mario du disinisabantar om mau putarfelem itu

Berisik..bunyi motor..B : io mari sini ambil c felem

A:felemcumatigasaja,Sengsebentar ganti e kasi pinda kaka atuas data di empagigayotarufelemdi delapan giga tu

C : kanapa..kanapa.kanapaBerisik....bunyi motor.......

A:mari sinilah mama bilang ini par diaBerisik...motor.......

B:kaka Atus bilang to dari situ trus taputar bagini.

ketawa.. hehehe....batuk...C:mengapa?

A : mau pigi sekolah $\mathrm{k}$ seng?

C: seng

A:he,cpotongbungabmanyasal deng

akang $\mathrm{k}$

D: aduh ya tuang eee.

A: adi...adi su makan $\mathrm{k}$ balom?miyo su makan $\mathrm{k}$ balom?

C : suda

A :sapa dong?ade makan apa?Berisik.... kalau su mabo tu jang baribot talalu. Bunyi motor, Pahat.. dong mabo dong baribot oooh.

A :adi makan apa?diabilangfelemblet barang dia bilangdiahitam samadengdiabapatoma felem Atus.. Atus. batu badaong?

60 | BASINDO : Jurnal Kajian Bahasa, Sastra Indonesia, dan Pembelajarannya 
C: seng batu badaong seng. Berisik.... ketawa.... hehhhehehe

A:ataus talucu pece. $C$, nene ema tumbak c,tete emi mati sudah tu

C: mana, mana felem?Mario bobo jua

A: ia pi tidur sudah.

\section{Faktor Pendorong Pergeseran Bahasa Alune Di Desa Murnaten Kecamatan Taniwel Kabupaten Seram Bagian Barat Ambon}

Faktor-faktor pendorong pergeseran bahasa Alune di Desa Murnaten Kecamatan Taniwel Kabupaten Seram Bagian Barat Ambon dapat dilihat sebagai berikut. Pertama, factor kedwibahasaan yang dimiliki oleh masyarakat Desa Murnaten Kecamatan Taniwel Kabupaten Seram Bagian Barat Ambon. Hal ini dimaksudkan bahwa salah satu faktor yang mengakibatkan pergeseran bahasa Alune pada masyarakat Desa Murnaten disebabkan karena masyarakat menguasai lebih dari satu bahasa yaitu bahasa Alune, bahasa Melayu Ambon dan bahasa Indonesia.

Kedua, factor migrasi atau perpindahan penduduk di Desa Murnaten Kecamatan Taniwel Kabupaten Seram Bagian Barat Ambon. Dalam penelitian ini peneliti menemukan migrasi atau perpindahan penduduk oleh kebanyakan penduduk di Desa Murnaten, melalui hasil angket dan hasil wawancara. Dari hasil angket yang dibagikan terdapat pilihan tempat yang sering dikunjungi oleh masyarakat Desa Murnaten yaitu Kecamatan Pirudan Kota Ambon. Selain itu dari hasil wawancara dengan sekretaris desa dan raja desa Murnaten didapatkan bahwa hampir setiap tahun, 60-80 penduduk bermigrasi ke Kecamatan Piru dan Kota Ambon. Alasan penduduk berimigrasi ke Kecamatan Piru dan Kota Ambon untuk kebutuhan sekolah; SD,SMP,SMA/SMK, perguruan tinggi dan mencarai lapangan pekerjaan.

Ketiga, factor sekolah merupakan salah satu faktor yang mempengaruhi bahasa Alune khususnya pada anak di Desa Murnaten Kecamatan Taniwel Kabupaten Seram Bagian Barat Ambon. Melalui hasil pemantauan secara langsung dan wawancara dengan beberapa guru di sekolah, bahwa pada proses belajar mengajar di kelas guru dan siswa dituntut menggunakan bahasa Indonesia.

Keempat, factor keluarga merupakan salah satu faktor yang mempengaruhi bahasa Alunedi Desa Murnaten Kecamtan Taniwel Kabupaten Seram Bagian Barat Ambon. Artinya, penggunaan bahasa Alune sebagai bahasa adat (bahasa ibu) tidak diturunkan oleh orangtua ke anak. Orang tua di Desa Murnaten Kecamatan Taniwel Kabupaten Seram Bagian Barat Ambon menggunakan bahasa dalam komunikasi dengan anak setiap hari, yaitu bahasa Melayu Ambon dan bukan bahasa Alune sebagai bahasa adat. Hal ini juga dipengaruhi oleh faktor kedwibahasawan yang dimiliki oleh orang tua sehingga tidak mengontrol penggunaan bahasa ke anak.

\section{Tipe Pemertahanan Bahasa Alune Di Desa Murnaten, Kecamatan Taniwel Kabupaten Seram Bagian Barat Ambon}

Penelitian mengenai tipe pemertahanan bahasa Alune di Desa Murnaten Kecamatan Taniwel Kabupaten Seram Bagian Barat Ambon, ditemukan adanya dua tipe pemertahanan yaitu pemertahanan bahasa pasif dan pemertahanan aktif. Selain itu tipe pemertahanan bahasa pasif dan aktif hanya di temukan pada orang tua tetapi tidak di temukan pada anak.

Prosespenggunaan bahasa Alune oleh orang tua di Desa Murnaten akan disesuaikan dengan siapa lawan tuturnya dab tempat peristiwa komunikasi. Namun, orang tua di Desa Murnaten ketika menggunakan bahasa Alune terjadi selalu terjadi pencampuran kode dari bahasa Alune ke bahasa Melayu Ambon dan Indonesia. Data berikut akan dilihat bahasa Alune yang digunakan orangtua dengan orangtua yang lain dalam ranah ketetanggaan.

Orang tua 1: Tuane ale keu teka?

Orang tua II: au keu pai minu

Orang tua I: amu paku buasia meo?

Orang II: au pakusa mo.

Orang I: ale keu atenane ainyai pi marabona?

Orang II: elo, keu atanene ainyai mina.

Orang I:dong kaya suda

Orang II: elo iti hole me minu mina.

Orang I: Bajalang bae-bae 0

Lamate kenamu

Orang II: lamate kenamu lekwe

\section{E. Faktor Pemertahanan Bahasa Alune Di Desa Murnaten Kecamatan Taniwel Kabupaten Seram Bagian Barat Ambon}

61 | BASINDO : Jurnal Kajian Bahasa, Sastra Indonesia, dan Pembelajarannya 
Penggunaan atau pola penggunaan bahasa, telah dijelaskan pula mengenai situasi penggunaan bahasa Alune di Desa Murnaten Kecamatan Taniwel Kabupaten Seram Bagian Barat Ambon. Berdasarkan tabel skala implikasi sudah terlihat bahwa bahasa Alune hanya bisa digunakan orang tua berumur 46 tahun keatas dalam ranah- ranah tertentu yaitu keluarga, pelantikan seorang pemimpin desa/raja, pelamaran seorang gadis untuk dinikahi dan ketika orang tua berumur 30 tahun keatas bertemu dengan orangtua yang sama umurnya baru ada kamunikasi yang mengunakan bahasa Alune. Namun, penggunaan bahasa Alune untuk anak berumur 5-11 tahun tidak lagi mengetahui sehingga tidak padat menggunakan bahasa Alune dalam komunikasi sehari-hari melainkan bahasa Melayu Ambon. Hal ini menunjukan bahwa pewarisan bahasa Alune atau bahasa adat yang menjadi bahasai budi Desa Murnaten Kecamatan Taniwel Kabupaten Seram Bagian Barat Ambon tidak diwariskan dari orang tua ke anak.

Berdasarkan hal tersebut maka pemertahanan bahasa Alune atau bahasa adat yang sebagai bahasa ibu hanya berada pada kalangan orangtua di Desa Murnaten Kecamatan Taniwel Kabupaten Seram Bagian Barat Ambon. Beberapa faktor pemertahanan bahasa Alune Desa Muranten Kecamatan Taniwel Kabupaten Seram Bagian Barat Ambon, dipengaruhi juga oleh kosentrasi wilayah pemukiman dan loyalitas masyarakattutur. Loyal yang dimaksud adalah sikap kesetiaan masyarakat untuk menggunakan bahasa Alune pada setiap ranah bahasa yang ada di Desa Murnaten.

\section{F. Strategi Pemertahanan Bahasa Alune di Desa Murnaten Kecamatan Taniwel Kabupaten Seram Bagian Barat Ambon.}

Mengenai strategi pemertahanan bahasa Alune di Desa Murnaten Kecamatan Taniwel Kabupaten Seram Bagian Barat Ambon, tidak ditemukan adanya strategi pemertahanan sesuai teori penelitian. Namun, strategi pemertahanan yang ada di Desa Murnaten hanya terdapat pada ranah keluarga dan pemerintahan desa yaitu pada pelaksanaan pelamaran, pelantikan pemimpin desa/raja dan percakapan orang tua umur 46 tahun keatas dengan teman sesame umurnya. Hal tersebut dapat dijelaskan bahwa pada proses pelamaran dan pelantikan pemimpin desa/raja di Desa Murnaten selalu menggunakan sistem adat dan bahasa Alune sebagai alat komunikasi dan bahasa Alune hanya diketahui oleh orang tua umur 46 tahun keatas.

Jadi, dapat disimpulkan bahwa dalam penelitian ini peneliti tidak menemukan srategi pemertahanan bahasa Alune oleh masyarakat Murnaten yan gsesuai dengan teori penelitian. Namun, dalam penelitian ini ditemukan strategi pemertahanan bahasa Alune hanya berada pada kalangan orang tua pada ranah keluarga dan pemerintahan desa yaitu pelaksanaan pelamaran dan pelantikan pemimpindesa/raja dan percakapan orang tua umur 46 tahun keatas dengan teman seumurnya. Oleh sebab itu pemertahanan bahasa Alune hanya berada pada kalangan orang tua tetapi tidak untuk anak di Desa Murnaten Kecamatan Taniwel Kabupaten Seram Bagian Barat Ambon.

\section{PENUTUP}

a. Simpulan

Berdasarkan hasil penelitian dan pembahasan hasil penelitian yang telah dipaparkan pada babbabsebelumnya, dapat disimpulkanhal-hal sebagai berikut.

Simpulan secara umum bahwa pemertahanan bahasa Alune di Desa Murnaten Kecamatan Taniwel Kabupaten Seram Bagian Barat Ambon hanya diketahui dan digunakan oleh orang tua tetapi anak tidak dapat menggunakannya lagi. Hal ini berdasarkan simpulan khusus berikut ini. Secara khusus dapat disimpulkan sebagai berikut.

Pertama, penggunaan bahasa Alune di Desa Murnaten Kecamatan Taniwel Kabupaten Seram Bagian Barat Ambon, terdapat 3 pola yaitu (1) pola penggunaan bahasa Alune dalam pelaksanaan pelantikan pemimpin desa/raja. (2) pola penggunaan bahasa Alune dalam pelaksanaan pelamaran, yang terbagi lagi menjadi tiga yaitu (a) pelamaran atau masuk minta secara resmi,(b) kawin menua, dan (c) kawin lari. (3) pola penggunaan bahasa Alune dalam percakapan orang tua dengan teman seumurannya di Desa Murnaten Kecamatan Taniwel Kabupaten Seram Bagian Barat Ambon.

Kedua, pergeseran bahasa Alune di Desa Murnaten dalam penggunaan bahasa pada setiap ranah kehidupan social dipengaruhi oleh factor kedwibahasaan yang dimiliki oleh orang tua dan ditemukan bahasa yang dominan digunakan oleh masyarakat yaitu bahasa Melayu Ambon. Bahasa Alune di Desa Murnaten Kecamatan Taniwel Kabupaten Seram Bagian Barat Ambon telah mengalami pergeseran bahasa melalui alih generasi (intergenerasi), yaitu generasi I ke generasi II dan ke generasi III.

Ketiga, factor pendorong pergeseran bahasaAlunedi Desa Murnaten Kecamatan Taniwel Kabupaten Seram Bagian Barat Ambon dapat dilihat sebagai berikut. Pertama, factor kedwibahasaan yang dimiliki oleh masyarakat Desa Murnaten Kecamatan Taniwel Kabupaten Seram Bagian Barat Ambon. Kedua, factor migrasi atau perpindahan pendudukdi Desa Murnaten Kecamatan Taniwel Kabupaten Seram Bagian Barat 
Ambon. Ketiga, faktor sekolah merupakan salah satu faktor yang mempengaruhi bahasa Alune khususnya pada anak di Desa Murnaten Kecamatan Taniwel Kabupaten Seram Bagian Barat Ambon. Keempat, factor keluarga marupakan salah satu factor yang mempengaruhi bahasa Alune di Desa Murnaten Kecamtan Taniwel Kabupaten Seram Bagian Barat Ambon. Jadi, mengenai factor pendorong pergeseran bahasa Alune di Desa Murnaten Kecamatan Taniwel Kabupaten Seram Bagian Barat Ambon, peneliti menemukan beberapa factor yaitu factor kedwibahasawan, faktormigrasi, faktor sekolah dan faktor keluarga.

Keempat, tipe pemertahanan bahasa Alune di Desa Murnaten Kecamatan Taniwel Kabupaten Seram Bagian Barat Ambon, pada penelitian ini ditemukan bahwa terdapat satu tipe pemertahan bahasa yaitu tipe pemertahanan bahasa Alune pasif. Pemertahanan bahasa Alune pasif adalah masyarakat tutur bahasa Alune di Desa Murnaten ketika berada dalam konteks komunikasi dengan lawan tuturnya telah mengalami pencampuran kode dari bahasa Alune ke bahasa Melayu Ambon dan bahasa Indonesia.

Kelima, faktor pemertahanan bahasa Alune di Desa Murnaten Kecamatan Taniwel Kabupaten Seram Bagian Barat Ambon. Ditemukan Berdasarkan table skala implikasi sudah terlihat bahwa bahasa Alune hanya bisa digunakan orangtua berumur 46 tahun keatas dalam ranah-ranah tertentu yaitu keluarga, pelantikan seorang pemimpin desa/raja, pelamaran seorang gadis untuk dinikahi, pengumuman/informasi dan ketika orang tua berumur 46 tahun keatas bertemu dengan orangtua yang sama umurnya baru ada komunikasi yang mengunakan bahasa Alune. Akan tetapi penggunaan bahasa Alune untuk anak berumur 5 - 11 tahun tidak lagi menggunakan bahasa Alune dalam komunikasi sehari-hari melainkan bahasa Melayu Ambon. Hal ini menunjukan bahwa pewarisan bahasa Alune atau bahasa adat yang menjadi bahasa ibu di Desa Murnaten Kecamatan Taniwel Kabupaten Seram Bagian Barat Ambon tidak diwariskan dari orang tua ke anak. Beberapa faktor pemertahanan bahasa Alune desa Muranten Kecamatan Taniwel Kabupaten Seram Bagian Barat Ambon, dipengaruhi oleh kosentrasi wilayah pemukiman dan loyalitas masyarakat tutur.

Keenam, strategi pemertahanan bahasa Alune di Desa Murnaten Kecamatan Taniwel Kabupaten Seram Bagian Barat Ambon, tidak ditemukan adanya strategi pemertahanan sesuai teori penelitian. Namun, strategi pemertahanan yang ada di Desa Murnaten hanya terdapat pada ranah keluarga dan pemerintahan desa yaitu pada pelaksanaan pelamaran, pelantikan pemimpin desa/raja dan percakapan orang tua umur 46 tahun keatas dengan teman sesame umurnya. Hal tersebut dapat dijelaskan bahwa pada proses pelamaran dan pelantikan pemimpin desa/raja di Desa Murnaten selalu menggunakan sistem adat dan bahasa Alune sebagai alat komunikasi dan bahasa Alune hanya diketahui oleh orang tua umur 46 tahun keatas.

Jadi, dapat disimpulkan bahwa dalam penelitian ini peneliti tidak menemukan srategi pemertahanan bahasa Alune oleh masyarakat Murnaten yang sesuai dengan teori penelitian. Namun, dalam penelitian ini ditemukan strategi pemertahanan bahasa Alune hanya berada pada kalangan orang tua pada ranah keluarga dan pemerintahan desa yaitu pelaksanaan pelamaran dan pelantikan pemimpin desa/raja dan percakapan orang tua umur 46 tahun keatas dengan teman seumurnya. Oleh sebab itu pemertahanan bahasa Alune hanya berada pada kalangan orang tua tetapi tidak untuk anak di Desa Murnaten Kecamatan Taniwel Kabupaten Seram Bagian Barat Ambon.

\section{b. Saran}

Penelitian ini masih mengungkap sebagian kecil masalah mengenai pergeseran dan pemertahanan bahasa Alune di Desa Murnaten Kecamatan Taniwel Kabupaten Seram Bagian Barat Ambon. Faktor eksternal, seperti sikap masyarakat Desa Murnaten Kecamatan Taniwel Kabupaten Seram Bagian Barat Ambon terhadap terhadap bahasa Alune, bahasa Melayu Ambon, bahasa Indonesia dan sikap masyarakat pendatang yang tinggal di Desa Murnaten terhadap bahasa Alune, bahasa Melayu Ambon dan bahasa Indonesia. Oleh sebab itu akan berpengaruh pada pemerolah bahasa sehingga mereka dapat mengetahui dan mennggunakan bahasa Alune, dan belum dikaji dalam penelitian. Hal tersebut tidak dikaji dalam penelitin ini, karena itu ada beberapa saran yang harus disampaikan.

1. Diperlukan peneliti lanjutan mengenai factor esternal pergeseran dan pemertahanan bahasa Alune di Kecamatan Taniwel Kabupaten Seram Bagian Barat Ambon.

2. Diperlukan peneliti lanjutan mengenai pergeseran dan pemertahanan bahasa Alune baik bersifat interdisipliner maupun antardisipliner. Selain itu, diperlukan juga penetapan sistem ejaan dan penulisan kamus bahasa Alune.

3. Dibutuhkan peneliti lanjutan mengenai peran bahasa Melayu Ambon dan bahasa Indonesia yang dapat mengakibatkan pergeseran bahasa Alune di Kecamatan Taniwel Kabupaten Seram Bagian Barat Ambon.

\section{DAFTAR RUJUKAN}


Aron, Meko Mbete. 2010. Strategi Pemertahanan Bahasa-Bahasa Nusantara. In: Seminar Nasional Pemertahanan Bahasa Nusantara, 6Mei2010,Hotel Pandanaran:Semarang.

Badulu, Abdul Muis dan Herman, M.S.(2004). Morfosintaksis. Jakarta: Rineka Cipta.

Basir, Udjang PR.M.2010. Sosiolinguistik (Pengantar Kajian Tindak Berbahasa). Surabaya: Bintang Surabaya.

Chaer, Abdul dan Agustina, Leonie. (2004). Sosiolinguistik Perkenalan Awal. Jakarta: RinekaCipta.

Google. (2016).www.ijhssne t.co m/jo urna ls/Vo 1_3_No.../28.pdf di unduh tanggal 27 Juli2016

Hukubun, Yohanis.(2010). Bentuk Sapaan dalam Bahasa Alune di Desa Murnaten Kecamatan Taniwel Kabupaten Seram Bagian Barat. SkripsiSarjanaPendidikan. UniversitasNegeriPattimura Ambon.

Laksono, Kisyani dan Savitri Agusniar Dini. (2009). Dialektologi. Surabaya: Unesa University Press.

Mahsun.(2013). Metode Penelitian Bahasa Tahapan Strategi, Metode dan Tekniknya. Jakarta: Raja Grafindo Persada.

Moleong, J. Lexi.(2014). Metodologi Penelitian Kualitatif. Bandung: Remaja Rosdakarya.

Nida, Eugena. A. (1949). Mophology. The Descriptive Analysis ofWords.Ann Abror: The University of Michigan.

Nasution, S. Prof. Dr. M.A.(2004). Metode Research (Penelitian Ilmiah). Jakarta: Bumi Aksara.

Ramadhanti, D. (2018). Pembentukan Karakter Melalui Ungkapan Kepercayaan Rakyat Dalam Masyarakat Minangkabau. Basindo : Jurnal Kajian Bahasa, Sastra Indonesia, dan Pembelajarannya, 1(2), 72 78.sa.Jakarta: Pusat Pembinaan dan Pengembangan Bahasa, Depertemen Pendidikan Bahasa dan Kebudayaan.

Sunarto. (2001). Metodologi Penelitian Ilmu-Ilmu Sosial dan Pendidikan. Surabaya : Unesa University Press. Sumarsono. (2014). Sosiolinguistik. Yogyakarta: Pustaka Pelajar.

Taber Mark dan A.Foster Leslie. (1996). Atlas Bahasa Tanah Maluku. Pusat Pengkajian dan Pengembangan Maluku Universitas Pattimura dan Summer Instituteof Linguistics.

64 | BASINDO : Jurnal Kajian Bahasa, Sastra Indonesia, dan Pembelajarannya 